- Letter

\title{
Citric Acid as an Alternative to Boric Acid in the Treatment of Chronic Suppurative Otitis Media
}

\author{
Basavraj Nagoba*, Milind Davane \\ Department of Microbiology, MIMSR Medical College, Latur, India
}

\section{To the Editor}

We read with interest the review by Adriztina et al. ${ }^{1)}$ regarding the efficacy and toxicity of boric acid in the treatment of patients with chronic suppurative otitis media (CSOM). The authors focused on the safety of boric acid at higher concentrations than those recommended for human use. In this regard, we would like to mention that despite its less frequent use as a topical agent in the treatment of wound infections, especially those caused by Pseudomonas aeruginosa, boric acid is highly effective and safe at a concentration of $3 \%{ }^{2,3)}$ Moreover, it is reported to be effective in the treatment of patients with CSOM, especially at a high concentration. ${ }^{4,5}$ Although the safety of a $4 \%$ boric acid solution prepared in distilled water versus boric acid solution in $70 \%$ alcohol, is shown in animal studies, ${ }^{1,6)}$ its safety for use in humans remains unknown. We are in agreement with the view of Adriztina et al. ${ }^{1)}$ that further studies are required in patients with CSOM to evaluate the treatment outcomes of boric acid and its associated ototoxicity at high concentrations.

Considering the questionable safety of boric acid, we suggest the use of $2 \%-3 \%$ citric acid as an alternate treatment option. Citric acid is a natural product obtained from citrus fruits. It has a wide range of antibacterial activity, inhibiting most bacterial pathogens commonly associated with various wounds. It has proven efficacy and safety as treatment in patients with various wound infections such as burns and postoperative wounds, as well as wounds of HIV/AIDS (human immunodeficiency virus infection and acquired immune deficiency syndrome) patients and tuberculous ulcers. In addition, it is known to promote healing. ${ }^{7-10)}$ No adverse or unsafe effects are reported except for local irritation for a few minutes post-application, which can be minimized by adding local anesthetic agents such as lidocaine.

In view of the restricted range of antibacterial activity of boric acid and safety issue, $2 \%$ or $3 \%$ citric acid is suggested as one of the best alternatives.

\section{CONFLICT OF INTEREST}

No potential conflict of interest relevant to this article was reported.

\section{ORCID}

Basavraj Nagoba: https://orcid.org/0000-0001-5625-3777

Milind Davane: https://orcid.org/0000-0002-9158-1167

\section{REFERENCES}

1. Adriztina I, Adenin LI, Lubis YM. Efficacy of boric acid as a treatment of choice for chronic suppurative otitis media and its ototoxicity. Korean J Fam Med 2018;39:2-9.

2. Kujath P, Hugelschaffer C. Pseudomonas aeruginosa: pathogenicity, prevention and therapeutic approaches. Zentralbl Chir 1987;112:558-63.

3. Borrelly J, Blech MF, Grosdidier G, Martin-Thomas C, Hartemann P. Contribution of a $3 \%$ solution of boric acid in the treatment of deep wounds with loss of substance. Ann Chir Plast Esthet 1991;36:65-9.

4. Minja BM, Moshi NH, Ingvarsson L, Bastos I, Grenner J. Chronic suppurative otitis media in Tanzanian school chil- 
dren and its effects on hearing. East Afr Med J 2006;83:322-5.

5. Loock JW. A randomised controlled trial of active chronic otitis media comparing courses of eardrops versus one-off topical treatments suitable for primary, secondary and tertiary healthcare settings. Clin Otolaryngol 2012;37:261-70.

6. Ozturkcan S, Dundar R, Katilmis H, Ilknur AE, Aktas S, Haciomeroglu $\mathrm{S}$. The ototoxic effect of boric acid solutions applied into the middle ear of guinea pigs. Eur Arch Otorhinolaryngol 2009;266:663-7.

7. Nagoba BS, Gandhi RC, Hartalkar AR, Wadher BJ, Selkar SP. Simple, effective and affordable approach for the treatment of burns infec- tions. Burns 2010;36:1242-7.

8. Nagoba B, Patil Dawale C, Raju R, Wadher B, Chidrawar S, Selkar S, et al. Citric acid treatment of post operative wound infections in HIV/ AIDS patients. J Tissue Viability 2014;23:24-8.

9. Hartalkar A, Nagoba B. Tuberculous inguinal lymphadenitis with multiple discharging sinuses: an unusual presentation. Indian J Surg 2013;75:149-50.

10. Nagoba B, Gandhi R, Wadher B, Rao A, Selkar S. Simple and effective approach for the treatment of traumatic wounds in non-diabetic patients: a prospective open study. Int Wound J 2013;10:585-9. 